\title{
PENGARUH PEMBERIAN REWARD TERHADAP HASIL BELAJAR PADA MATA PELAJARAN MATEMATIKA KELAS V SDN 094097 SIMPANG PONGKALAN TONGAH KABUPATEN SIMALUNGUN
}

\author{
Priskila R Sipayung, Regina Sipayung, Dyan W.S HS, Darinda Sofia Tanjung \\ Surel : priskilasipayung9@ gmail.com
}

\begin{abstract}
This study aims to determine the effect of giving rewards on learning outcomes in fifth grade mathematics subjects at SDN 094097 Simpang Pongkalan Tongah. The research method used is an experimental method with quantitative research. To obtain the necessary data in the form of a test with a total of 40 questions. The research at SDN 094097 Simpang Pongkalan Tongah in class $V$ was carried out from 10 to 11 May 2021. The number of research samples was 16 students based on the saturated sample technique. The results of statistical calculations show that the ability of students in answering post-test questions with the reward method is included in the very good category with an average value of 84.06 in the very good category. Meanwhile, the students' ability to answer the post-test questions with the demonstration method was included in the good category with an average value of 70.31 in the good category. This study used the normality test with the results of 0.200>0.05. Then the homogeneity test with a significance value of $0.344>0.05$. Furthermore, hypothesis testing is to compare the value of $t_{\text {count }}$ with $t_{\text {table. }}$. Obtained the value of $t_{\text {count }}=4.111$ while $t_{\text {table }}=1.746$. Because $t_{\text {count }}>t_{\text {table }}(4.111>1.746)$ then $H_{a}$ is accepted and $H_{o}$ is rejected. Through the t test, it can be concluded that there is a significant effect between giving rewards to learning outcomes.
\end{abstract}

Keywords: Giving Rewards, Mathematics, Learning Outcomes

\begin{abstract}
ABSTRAK
Penelitian ini bertujuan untuk mengetahui pengaruh pemberian reward terhadap hasil belajar pada mata pelajaran matematika kelas V di SDN 094097 Simpang Pongkalan Tongah. Metode penelitian yang digunakan adalah metode eksperimen dengan jenis penelitian kuantitatif. Untuk memperoleh data yang diperlukan berupa test dengan jumlah 40 pertanyaan. Penelitian di SDN 094097 Simpang Pongkalan Tongah pada kelas V dilaksanakan pada tanggal 10 sampai 11 Mei 2021. Jumlah sampel penelitian sebanyak 16 siswa berdasarkan teknik sampel jenuh. Hasil perhitungan statistik menunjukkan bahwa kemampuan siswa dalam menjawab soal post test dengan metode pemberian reward termasuk dalam kategori baik sekali dengan nilai rata-rata 84,06 kategori baik sekali. Sedangkan kemampuan siswa dalam menjawab soal post test dengan metode demonstrasi, termasuk dalam kategori baik dengan nilai rata-rata 70,31 kategori baik. Penelitian ini menggunakan uji normalitas dengan hasil 0,200>0,05. Kemudian uji homogenitas dengan nilai signifikansi $0,344>0,05$. Selanjutnya pengujian hipotesis yaitu membandingkan nilai $t_{\text {hitung }}$ dengan $t_{\text {tabel. }}$. Diperoleh nilai $t_{\text {hitung }}=4,111$ sedangkan $\mathrm{t}_{\text {tabel }}=1,746$. Karena $\mathrm{t}_{\text {hitung }}>\mathrm{t}_{\text {tabel }}(4,111>1,746)$ maka $\mathrm{H}_{\mathrm{a}}$ diterima dan $\mathrm{H}_{\mathrm{o}}$ ditolak. Melalui uji $\mathrm{t}$ tersebut dapat disimpulkan bahwa terdapat pengaruh yang siginifikan antara pemberian reward terhadap hasil belajar.
\end{abstract}

Kata Kunci: Pemberian Reward, Matematika, Hasil Belajar 
Priskila Sipayung, Regina Sipayung, Dyan W.S HS, Darinda S. Tanjung : Pengaruh ...

\section{PENDAHULUAN}

Pendidikan dibutuhkan oleh setiap individu dalam setiap proses hidupnya. Untuk itu pendidikan merupakan kebutuhan sepanjang hayat (long life education). Di Negara Indonesia, pendidikan adalah suatu kewajiban setiap manusia yang disebut dengan wajib belajar. Wajib belajar 12 tahun yaitu, selama 6 tahun berada di pendidikan dasar, selama 3 tahun berada di pendidikan menengah pertama serta selama 3 tahun berada pada pendidikan menengah atas.

Pendidikan dasar sebagai hal utama untuk setiap individu dalam meningkatkan kualitas pendidikan sebagai bekal untuk masa depan. Untuk mendapatkan bekal yang baik, perlu usaha maksimal dari guru dan siswa dalam kegiatan belajar. Untuk itu, guru dan siswa diharapkan bisa bekerjasama untuk mencapai tujuan dari pembelajaran tersebut.

Menjadi guru tidaklah mudah karena guru sebagai pribadi yang ditiru oleh siswanya sendiri. Guru merupakan suatu profesi yang memiliki keahlian khusus di dalam bidang pendidikan. Tugas guru adalah mendidik, mengajar, memfasilitasi,merancang, mengelola dan menilai.

Membangun hubungan yang baik dengan siswa harus mampu menciptakan suasana yang tidak membosankan, kreatif dan inovatif. Suasana yang diinginkan yaitu guru harus mampu mencairkan suasana disela-sela pembelajaran, seperti guru harus mempunyai sifat yang humoris, guru melibatkan siswa di dalam proses pembelajaran, dan guru memberikan reward (penghargaan) kepada siswa.

Reward (penghargaan) adalah alat untuk mendidik siswa supaya merasa senang karena perbuatan dan pekerjaannya yang mendapat sebuah penghargaan. Nilai yang bagus, hadiah, pujian atau perlakuan yang baik kepada siswa disebut dengan reward positif. Sedangkan reward negatif dapat berupa hukuman dengan perkataan, hukuman dengan perbuatan, ataupun hukuman dengan isyarat.

Pemberian reward atau penghargaan memiliki fungsi penting sebagai nilai dalam mendidik, sebagai motivasi untuk siswa selalu melakukan dan mempertahankan perilaku yang baik dalam kehidupan sehari-hari. Dengan pemberian rewardakan memberikan pengaruh kepada suasana hati siswa tersebut. Pengaruh berikutnya yaitu akan meningkatkan minat dan hasil belajar siswa.

Karakteristik siswa sekolah dasar secara umum yaitu rasa ingin tahu yang tinggi, mempunyai minat belajar pada mata pelajaran yang khusus dan memandang nilai merupakan alat ukur mengenai prestasi di sekolah. Seperti karakteristik siswa kelas V SD pasti berbeda-beda baik perilaku maupun sifat. Salah satu cara untuk mengenali karaktertistik siswa dengan cara memberikan reward (penghargaan). Sehingga jika guru sudah mengenali karakteristik siswanya dapat menumbuhkan minat belajar dan 
meningkatkan hasil belajar siswa dalam mata pelajaran matematika.

Mata pelajaran matematika merupakan salah satu mata pelajaran yang dipelajari oleh semua jenjang pendidikan. Mata pelajaran matematika adalah pelajaran yang berisi tentang perhitungan yang menuntut siswa untuk berfikir secara kritis, logis, tekun, kreatif dan inisiatif. Guru harus mampu meyakinkan kepada siswa bahwa matematika bukanlah pelajaran yang menakutkan dan membosankan.

Sesuai dengan informasi awal di lokasi penelitian yang sudah dilaksanakan dalam observasi awal, bahwa guru di dalam kelas kurang ekspresif dan guru kurang inisiatif dalam memberikan reward kepada siswa sehingga minat belajar kurang dan hasil belajar rendah.

Hasil belajar merupakan kemampuan yang dicapai oleh siswa baik dari aspek afektif, kognitif dan psikomotorik. Diketahui hasil belajar siswa kelas V di SDN 094097 Simpang Pongkalan Tongah dalam mata pelajaran matematika belum cukup maksimal dan ada beberapa siswa yang menunjukkan bahwa hasil belajarnya belum mencapai ketuntasan minimum. Sementara nilai KKM yang hendak dicapai pada mata pelajaran matematika di kelas $\mathrm{V}$ adalah 65 yang menunjukkan hasil peningkatan mean (rata-rata) dari 65,63 berada dalam kategori cukup dan menjadi 79,75 menjadi kategori baik.

Dalam hal itu, peneliti memberi perhatian pada Siswa Kelas V SDN
094097 Simpang Pongkalan Tongah Kecamatan Dolok Masagal Kabupaten Simalungun. Dimana pemberian reward menjadi salah satu cara yang digunakan guru dalam proses pembelajaran untuk meningkatkan hasil belajar siswa pada mata pelajaran matematika materi pecahan.

\section{METODE PENELITIAN}

Penelitian ini menggunakan metode eksperimen, dengan cara langsung ke sekolah untuk memperoleh data-data yang dibutuhkan untuk melihat pengaruh bagaimana pemberian reward terhadap hasil belajar. Sebagai pupulasi sebanyak 127 siswa terdiri dari 6 kelas. Peneliti memilih kelas V yang memiliki jumlah siswa sebanyak 32 siswa. Untuk kelas kontrol terdiri dari 16 siswa dan kelas eksperimen sebanyak 16 siswa. Pengambilan sampel dilakukan secara sampel jenuh. Untuk memperoleh data yang diperlukan diberikan post test berjumlah 40 soal matematika kepada siswa kelas V SDN 094097 Simpang Pongkalan Tongah, Kabupaten Simalungun Tahun Pembelajaran 2020/2021.

\section{HASIL PENELITIAN DAN PEMBAHASAN}

Dalam penelitian untuk melihat bagaimana pengaruh dari pemberian metode reward terhadap hasil belajar mata pelajaran matematika kelas $\mathrm{V}$ di SDN 094097 Simpang Pongkalan Tongah, Kabupaten Simalungun Tahun Pembelajaran 2020/2021. 
Priskila Sipayung, Regina Sipayung, Dyan W.S HS, Darinda S. Tanjung : Pengaruh ...

Diberikan 40 soal pilihan berganda post test dengan jumlah soal 40 kepada kelas kontrol dan kelas eksperimen. Untuk Kriteria Ketentuan Minimal (KKM) yaitu 65. Data dari hasil post test kelas eksperimen yang diberikan perlakuan metode reward dapat dilihat dari tabel distribusi frekeunsi pada tabel 1 dibawah ini.

Tabel 1. Distribusi Frekuensi Post Test Kelas Eksperimen

\begin{tabular}{c|c|c|c}
\hline No & $\begin{array}{c}\text { Nilai } \\
(\mathbf{X})\end{array}$ & $\begin{array}{c}\text { Frekuensi } \\
(\mathbf{F})\end{array}$ & $\mathbf{F X}$ \\
\hline 1 & 65 & 1 & 65 \\
\hline 2 & 70 & 1 & 70 \\
\hline 3 & 75 & 2 & 150 \\
\hline 4 & 80 & 4 & 320 \\
\hline 5 & 85 & 2 & 170 \\
\hline 6 & 90 & 2 & 180 \\
\hline 7 & 95 & 2 & 190 \\
\hline 8 & 100 & 2 & 200 \\
\hline Jumlah & \multicolumn{3}{|c}{84,06} \\
\hline Rata-rata & \multicolumn{3}{|c}{} \\
\hline
\end{tabular}

Diperoleh nilai rata-rata yaitu 84,06 dengan kategori baik sesuai tabel 2 kriteria penilaian sebagai berikut.

Tabel 2. Kriteria Penilaian

\begin{tabular}{c|c}
\hline $\begin{array}{c}\text { Kriteria } \\
\text { Penelitian }\end{array}$ & Keterangan \\
\hline $80-100$ & Baik sekali \\
\hline $70-79$ & Baik \\
\hline $60-69$ & Cukup \\
\hline $50-59$ & Kurang \\
\hline $0-49$ & Gagal \\
\hline
\end{tabular}

Sedangkan hasil post test kelas kontrol yang menggunakan metode demonstrasi dapat dilihat dari tabel distribusi frekuensi pada tabel 2 dibawah ini.
Tabel 3. Distribusi Frekuensi Post Test Kelas Kontrol

\begin{tabular}{|c|c|c|c|}
\hline No & $\begin{array}{l}\text { Nilai } \\
(\mathrm{X})\end{array}$ & $\begin{array}{c}\text { Frekuensi } \\
\text { (F) }\end{array}$ & FX \\
\hline 1 & 55 & 1 & 55 \\
\hline 2 & 60 & 2 & 120 \\
\hline 3 & 65 & 3 & 195 \\
\hline 4 & 70 & 4 & 280 \\
\hline 5 & 75 & 2 & 150 \\
\hline 6 & 80 & 3 & 240 \\
\hline 7 & 85 & 1 & 85 \\
\hline Jumlah & & 16 & 1125 \\
\hline $\begin{array}{c}\text { Rata- } \\
\text { rata }\end{array}$ & & \multicolumn{2}{|c|}{70,31} \\
\hline
\end{tabular}

Diperoleh nilai rata-rata yaitu 70,31 dengan kategori baik tabel 2 kriteria penilaian diatas. Gambaran tabel distribusi frekuensi post test kelas eksperimen dan kelas kontrol dapat dilihat pada histogram dibawah ini :

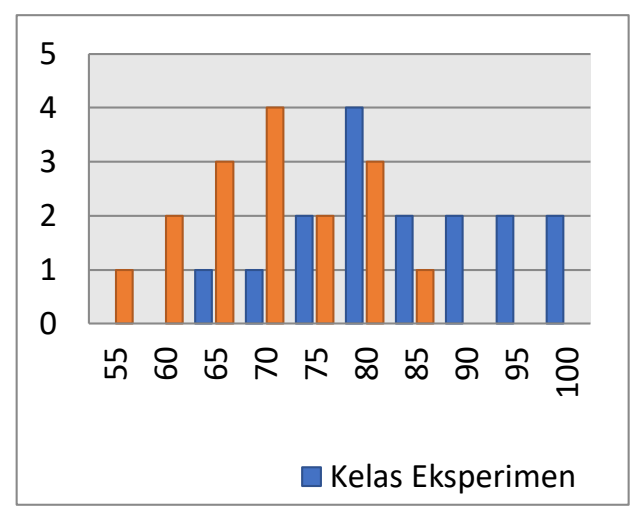

\section{Gambar 1. Histogram Distribusi Frekuensi Post Test Kelas Eksperimen dan Kelas Kontrol}


Selanjutnya dilakukan uji normalitas untuk mengetahui apakah dalam penelitian tersebut berdistribusi normal atau tidak. Setelah melalui perhitungan menggunakan SPSS untuk pengujian normalitas melalui uji KolmogorovSmirnov (K-S), diperoleh nilai signifikan 0,200>0,05 maka dapat disimpulkan bahwa data berdistribusi normal.

Tabel 4. Uji Normalitas

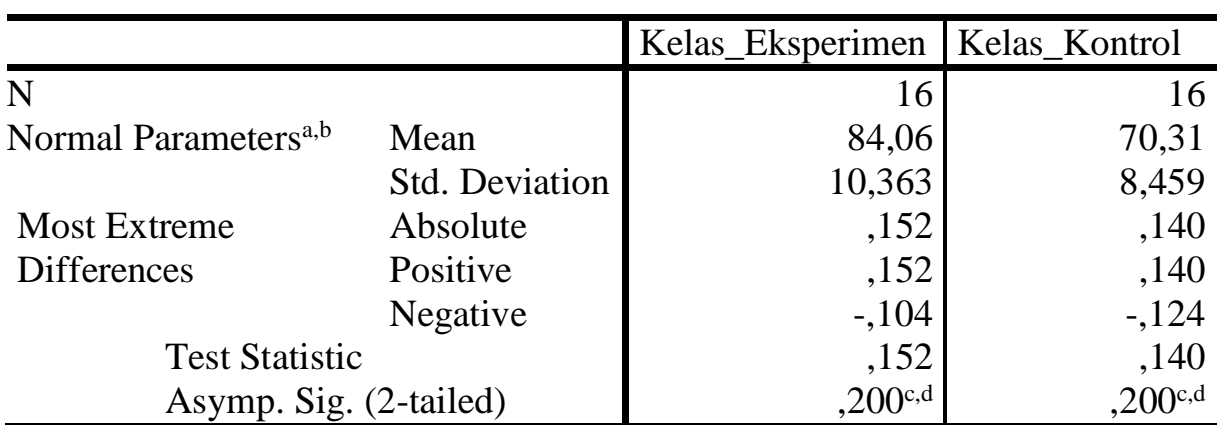

Kemudian untuk melihat apakah data berdistribusi homogen, peneliti melakukan uji homogenitas. Dengan menggunakan SPSS dapat diketahui nilai signifikansi 0,344>0,05. Maka dapat disimpulkan data tersebut berdistribusi homogen.

Tabel 5. Uji Homogenitas

\begin{tabular}{l|l|r|r|r|r}
\hline \multicolumn{2}{l|}{} & \multicolumn{1}{c|}{$\begin{array}{c}\text { Levene } \\
\text { Statistic }\end{array}$} & f1 & \multicolumn{1}{c|}{ f2 } & Sig. \\
\hline $\begin{array}{l}\text { Hasil Belajar } \\
\text { Siswa }\end{array}$ & $\begin{array}{l}\text { Based on } \\
\text { Mean }\end{array}$ &, 923 & & & 0
\end{tabular}

\section{Pembahasan}

Berdasarkan hasil uji hipotesis menunjukkan bahwa terdapat pengaruh pemberian reward terhadap hasil belajar siswa mata pelajaran matematika kelas V SDN 094097 Simpang Pongkalan Tongah, Kabupaten Simalungun, Tahun Pembelajaran 2020/2021. Hal ini dibuktikan dengan pengujian hipotesis untuk membandingkan hasil nilai $t_{\text {hitung }}$ dengan $t_{\text {tabel}}$. Hasilnya menunjukkan nilai $t_{\text {hitung }}=4,111$ sedangkan $t_{\text {tabel }}=1,746 . \quad$ Karena $t_{\text {hitung }}>t_{\text {tabel }}(4,111>1,746)$ sehingga $\mathrm{H}_{a}$ diterima sedangkan $\mathrm{H}_{\mathrm{o}}$ ditolak.

\section{SIMPULAN}

Dari hasil analisis data yang telah dikemukakan maka kesimpulan yang dapat diperoleh adalah:

- Rata-rata nilai post test kelas eksperimen yang menggunakan pemberian metode reward pada kelas V mata pelajaran matematika di SDN 094097 
Priskila Sipayung, Regina Sipayung, Dyan W.S HS, Darinda S. Tanjung : Pengaruh ...

Simpang Pongkalan Tongah, Kabupaten Simalungun Tahun Pembelajaran 2020/2021 yaitu 84,06 dengan kategori baik sekali yang sudah melewati Kriteria Ketuntasan Minimal (KKM) sebesar 65.

- Peneliti melakukan uji normalitas pada penelitin ini. Hasil uji normalitas yaitu 0,200 $>0,05$ maka dapat disimpulkan bahwa data berdistribusi normal.

- Peneliti juga menggunakan uji homogenitas dari hasil post test kelas eksperimen dan kelas kontrol. Hasil dari uji homogenitas dapat diketahui nilai signifikansi $0,344>0,05$. Maka dapat disimpulkan data tersebut berdistribusi homogen.

- Uji hipotesis menunjukkan bahwa nilai thitung $=4,111$ sedangkan $t_{\text {tabel }}=1,746$. Karena $t_{\text {hitung }}>t_{\text {tabel }}(4,111>1,746)$ maka $\mathrm{H}_{\mathrm{a}}$ diterima dan $\mathrm{H}_{\mathrm{o}}$ ditolak. Sehingga terdapat pengaruh pemberian reward terhadap hasil belajar siswa mata pelajaran matematika kelas V SDN $094097 \quad$ Simpang Pongkalan Tongah, Kabupaten Simalungun, Tahun Pembelajaran 2020/2021.

\section{DAFTAR RUJUKAN}

Abdullah, A., \& Rosyid, M. 2018. Reward \& Punishment Dalam Pendidikan. Jakarta : Literasi Nusantara.

Arikunto. 2018. Prosedur Penelitian

(7th Ed.). Jakarta : Rineka

\section{Cipta.}

Dalyono, M. 2012. Psikologi Pendidikan (Ketujuh). Jakarta: Rineka Cipta.

Darmadi, H. 2014. Metode Penelitian Pendidikan Dan Sosial (Kesatu). Bandung : Alfabeta.

Djaali, H. 2014. Psikologi Pendidikan (1st Ed.). Bandung : Bumi Aksara.

Djamarah, S. 2019. Psikologi Belajar (Ketiga). Bandung : Rineka Cipta.

Hamalik, O. 2015. Kurikulum Dan Pembelajaran. Bandung : Bumi Aksara.

Hs, D. 2020. Perbedaan Sikap Ilmiah Siswa Menggunakan Model Pembelajaran Inquiry

Training Dengan Model Pembelajaran Direct Instruction. Jurnal Tunas Bangsa, 7, 174-187.

Huda, M. 2017. Model-Model Pengajaran Dan

Pembelajaran. Jakarta : Pustaka Pelajar.

Istarani. 2017. 58 Model Pembelajaran Inovatif (M. Siddik \& Abdussalarn (Eds.)). Bandung : Media Persada.

Khairani, M. 2017. Psikologi Belajar. Jakarta : Aswaja Pressindo.

Kompri. 2018. Motivasi Pembelajaran Perpektif Guru Dan Siswa (Kamsyach/Adriyani (Ed.); 2nd Ed.). Bandung : Remaja Rosdakarya.

Kosasih, N., \& Sumarna, D. 2013. Pembelajaran Quantum Dan Optimalisasi Kecerdasan (A. 
Rukajat (Ed.); 1st Ed.). Bandung : Alfabeta.

Kurniasih, \& Sani. 2016. Model Pembelajaran (A. Jay (Ed.); 4th Ed.). Surabaya : Kata Pena.

Mudjiono, \& Dimyati. 2015. Belajar Dan Pembelajaran. Bandung : Rineka Cipta.

Muliawan, J. 2016. 45 Model Pembelajaran Spektakuler (Nurhid (Ed.)). Surabaya : ArRuzz Media.

Mulisrarini, \& Hamzah, A. 2014. Perencanaan Dan Strategi Pembelajaran Matematika (I). Bandung : Rajagrafinfo Persada.

Pulungan, I., \& Istrani. 2018. Ensiklopedia Pendidikan (A. Sembiring \& M. Ridwan (Eds.); Kedua). Bandung : Mediapersada.

Purwanto. 2011. Evaluasi Hasil Belajar (Santosa/Budi (Ed.); Iii). Bandung : Pustaka Pelajar.

Rofiqi, U., \& Rosyid, M. 2019. Reward \& Punishment Konsep Dan Aplikasi (Mustajab (Ed.); I). Jakarta :
Literasi Nusantara.

Sardiman. 2014. Interaksi \& Motivasi Belajar Mengajar (22 (Ed.); 1st Ed.). Bandung : Rajagrafinfo Persada.

Sipayung, R., \& Tanjung, D. S. 2020. Pengaruh Pemberian Reward Terhadap Hasil Belajar Siswa Pada Mata Pelajaran Matematika Kelas Iv Sd Negeri 097350 Parbutaran. Jurnal Sekolah, 4 (September), 33-41.

Slameto. 2017. Belajar Dan FaktorFaktor Yang Mempengaruhinya (1st Ed.). Bandung : Rineka Cipta.

Sudjana. 2016. Metode Statistika (Ketujuh). Makassar : Tarsito. Sugiyono. 2017. Metode Penelitian Kuantitatif, Kualitatif, Dan $R \& D$. Bandung : Alfabeta.

Susanto, A. 2016. Teori Belajar Dan Pembelajaran Di Sekolah Dasar (Pertama). Jakarta : Prenadamedia Group.

Yusuf, S., \& Sugandhi, N. 2013. Perkembangan Peserta Didik. Bandung : Rajagrafinfo Persada. 